\title{
Peertechz
}
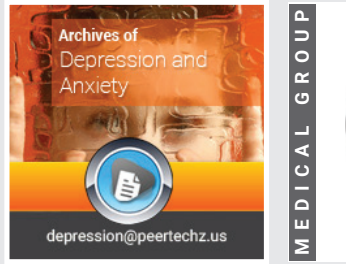

\section{Depths of despair: Experience}

\section{report}

\section{Maria Joana Nunes de Azevedo*}

Institute of Mathematics and Statistics, University of São Paulo, São Paulo, Brazil

Received: 06 May, 2021

Accepted: 28 September, 2021

Published: 29 September, 2021

*Corresponding author: Maria Joana Nunes de Azevedo, Institute of Mathematics and Statistics, University of São Paulo, São Paulo, Brazil, Tel: +55-92-99163-6597; E-mail: joanaazevedo@usp. br, ananunes.azevedo05@gmail.com

ORCID: https://orcid.org/0000-0002-3244-2837

Keywords: Despair; Depression; Anxiety

Copyright: (C) 2021 Nunes de Azevedo MJ. This is an open-access article distributed under the terms of the Creative Commons Attribution License, which permits unrestricted use, distribution, and reproduction in any medium, provided the original author and source are credited.

https://www.peertechzpublications.com

\section{Abstract}

Between 2017 and 2019 I went through the experience of depression and consequently I developed anxiety. In the beginning, in the months of November and December 2017, I found myself in a deep despair, not knowing how to identify what was happening. As an intervention, I went through consultations with the psychologist, where I had conversations, writing and positive affirmations. After these consultations I improved and got out of my depressed state. Awareness in the consultations with the psychologist made me realize how far I was from who I am and from this contact with a professional I was able to gain clarity about my condition and learned techniques to maintain my self-care constant

\section{Case report}

In the second half of 2017, it marked my first experience with the depressive state. At first, which was in November 2017, I did not know I was dealing with depression, in January 2018, at the encouragement of family members, I was taken to a psychologist and later diagnosed with mild depression. Before I knew the diagnosis, I had a routine medical check-up and the results were that I was healthy, so my family members were unable to identify what was happening to me. I also didn't know how to tell what was happening to me, I just felt like my physical energy was gone and my mind was tired, empty and like I couldn't think or even reason. My reflection felt blurry and like my vision had gotten tired so I just wanted to close my eyes. I thought it was just a 7 day phase and all the tired feeling would go away and then everything would be fine. But it ended up that it completed a month of this whole situation and did not return to my state that I considered "normal", which was my state of great vigor, that woman who could stand everything and who would not let herself rest, was an active woman. That first month I didn't have the energy to eat my meals, shower or eat. Just stood there and closed his eyes, and then despair came at being in that state, dependent on others to do the most basic tasks of everyday life. she cried a lot and couldn't say a word, couldn't ask for a glass of water, it was like she was in a coma, just listening to everything and immobile in a bed. Was waiting for someone to realize that was immobile and then the person saw that he needed help because he was crying, and then despaired because found myself in a world in which had never found myself, as if were in an inner darkness. In this dependent state stayed for two months (November and December 2017). After those two months, met the psychologist and started doing sessions with her. After these sessions noticed an improvement, as if my soul had returned to my body and started to have strength, energy and vigor to do my basic activities. The psychologist did not recommend medicine to me, she only did writing practices to identify valuesa nd identify my qualities and defects, and she told my whole story since was a child and did positive word affirmation practices in front of the mirror. After these practices was fine and stopped doing the sessions. In the second half of 2018 and 2019 had relapses and went back to doing the practices again and getting 
out of the depressed state again. The last time relapsed, which was in May 2019 until August of the same year, immersed myself in the process of self-knowledge and started to better understand what was really going through. It was in that last relapse of 2019 that I started to perceive anxiety and since then have tried to get around this feeling that when it gets intense it is as if were going to die. With self-knowledge, spirituality and self-love have overcome this state that is more appeased in me every day.
Discover a bigger Impact and Visibility of your article publication with

Peertechz Publications

\section{Highlights}

* Signatory publisher of ORCID

* Signatory Publisher of DORA (San Francisco Declaration on Research Assessment)

* Articles archived in worlds' renowned service providers such as Portico, CNKI, AGRIS, TDNet, Base (Bielefeld University Library), CrossRef, Scilit, J-Gate etc.

- Journals indexed in ICMJE, SHERPA/ROMEO, Google Scholar etc.

* OAI-PMH (Open Archives Initiative Protocol for Metadata Harvesting)

* Dedicated Editorial Board for every journal

* Accurate and rapid peer-review process

* Increased citations of published articles through promotions

* Reduced timeline for article publication

Submit your articles and experience a new surge in publication services (https://www.peertechz.com/submission). 